\title{
Archibald Alison, landscape painting, nature poetry and the landscape of the mind
}

\begin{abstract}
The subject of this article is the landscape of the mind. At the turn of the eighteenth and nineteenth centuries, in landscape painting and in nature poetry, the surrounding nature became an insignificant element of the artist's or poet's work, acting only as a trigger for introspection. In landscape painting, nature was supposed to express emotional states. The viewer was to embark on a mood suggested by the painting and immerse himself/herself in contemplation of his or her internal states. In nature poetry, such as William Wordsworth's Prelude, the vision of nature was subjective: its colouring was an effect of projection of the emotions of the speaker in the poem, it was a reflection of the landscape of his mind. The theoretical context to be used in this essay for the discussion of the landscape of the mind in landscape painting and nature poetry is the aesthetic theory of Archibald Alison.
\end{abstract}

Keywords: landscape painting, nature poetry, theory of associations, feelings, projection, beautiful, sublime.

\section{Introduction}

In the late eighteenth century, landscape painting and nature poetry gradually disentangled its links with the external world; the artist, the viewer of painting, and the speaker in a poem, instead of contemplating nature, were supposed to focus on the landscape of the mind, ${ }^{2}$ i.e., on their inner feelings and associations. The gradual shift from the external to the internal world, both in visual arts and in poetry, went hand in hand with similar changes in interest in the field of aesthetic theory. In the aesthetic philosophy we observe a departure from the interest in the objective standards of beauty and focus on the inner sphere of man, man's cognitive capacities, man's subjective aesthetic judgement, imagination and feelings. An important proponent of the thesis that art and

1 Address for correspondence: Wydział Humanistyczny, Uniwersytet Śląski w Katowicach, ul. Grota-Roweckiego 5, 41-200 Sosnowiec, Poland. E-mail: marta11lanna@gmail.com

2 I borrow the term "landscape of the mind" from Norman Lacey's critical study of William Wordsworth's poetry Wordsworth's View of Nature: And its Ethical Consequences (Lacey 1948: 98-99). 
poetry should explore the inner regions of the soul was Archibald Alison (1757-1839). The aim of this article is to analyze Archibald Alison's studies in aesthetics with special emphasis on his views on the beauty of nature. I want to show that a similar approach to the aesthetic value of nature that Alison promoted was visible in the artistic practice of his age, in the landscape painting and in nature poetry (with reference to the latter, I have chosen William Wordsworth, whose poetry is the most obvious example of the new approach to nature). I want to show that aesthetic theory, landscape painting and nature poetry started to focus on the landscape of the mind rather than on the external scene. In other words, I want to show that the paradoxical tendency to divert one's eyes from nature (i.e., the natural scene outside, the external world) was becoming a larger trend in the latter part of the eighteenth and the early nineteenth century, a trend that embraced aesthetic theory, landscape poetry and nature poetry.

I have chosen Alison's theory of taste as a representative aesthetic theory of the Romantic period. I compare his views to those represented in landscape painting of the same era and in nature poetry of the turn of the eighteenth century, using the example of William Wordsworth's The Prelude.

\section{Landscape painting and the internal world}

In the current part of my article I discuss Archibald Alison's views on landscape painting with special emphasis on his discussion of the landscape of the mind. I also present some opinions of the landscape painters themselves, who spoke in unison with Alison: the painters also claimed, that instead of representing a topography of a particular terrain, ${ }^{3}$ a picture should rather inspire the viewer to explore the inner landscape of his or her soul.

Archibald Alison, in his major work in the field of aesthetics entitled The Essays on the Nature and Principles of Taste, devotes several passages to landscape painting and explains that landscape art is, in fact, not supposed to imitate nature but to promote the viewer's interest in and curiosity about the landscape of the mind.

Alison speaks against the imitative landscape painting, which was popular in Britain in the seventeenth and eighteenth centuries. Imitative painting, of which the British topographic landscape is a prime subject, is for Alison inferior art, no matter how much skill of hand it demonstrates: "In the copy of a scene we can admire the skill (i.e., the mere mechanical dexterity of the artist)" but not "the genius" (Alison 1790: 89-90). He calls the authors of such paintings with a contemptible name "mere copiers of nature" (Alison 1790: 88) and denies them any touch of genius. Furthermore, he claims that the 
works of those "copiers" are for the unsophisticated audience unversed in visual arts (Alison 1790: 89). ${ }^{4}$

The weakness of imitative art, often overlooked by the uneducated viewers, is its lack of unity due to abundance of details. Such an imperfection disqualifies imitative paintings in the eyes of the demanding audience. They would not enjoy "the crowd of incidents", i.e., all the circumstantial details of a scene meticulously recreated in a picture. All the minute particulars rendered by a dexterous craftsman appear to the demanding viewers "as inconsistence or confusion" (Alison 1790: 84). They prefer a painting whose motifs are carefully selected, those only which are "congenial to our emotions" (Alison 1790: 84). The unity of emotion which, according to Alison is a true value of a good art, is disrupted in a literal copy of nature such as, for instance, a topographic landscape painting. In external nature there is "confusion of expression [...] which prevents him [a man of Taste] from indulging to the full, the peculiar emotion which the scene itself is fitted to inspire" (Alison 1790: 84). In other words, in a natural scene the dominant mood is often destroyed by elements which are incompatible with the overall atmosphere: "solemnity of noon" may be disrupted "by noise and bustling industry" while "the tranquillity and melancholy of evening [may be disrupted] by vivacity and vulgar gaiety" (Alison 1790: 84). The uniform atmosphere of a painting is essential as it triggers an analogous mood in the viewer and encourages him or her to explore the inner state inspired by the picture. Meanwhile, a spectator cannot be referred to his inner feelings by a landscape painting which is a copy of a real place, since such a painting lacks emotional coherence, with too many details disrupting the mood. Pruning out from the real scene anything that hinders its emotional unity is an accomplishment of a genius. A genius selects "from a thousand scenes, the circumstances which are to characterise a single composition, and may unite into one expression, the scattered features with which Nature has feebly marked a thousand situations" (Alison 1790: 87). He chooses, continues Alison, "the circumstances" which "give whatever force (...) he pleases to the expression he wishes to convey" (Alison 1790: 87). In other words, the work of a true artist is the careful presentation of elements, not necessarily coexisting in one external scene, which are similar in their mood and which together build up an emotionally coherent whole. Every detail which would interrupt the unity of mood created in the work of art is removed so as not to disturb the viewer, whose mind is set on reaching the emotional pitch tuned with the mood in the work of art.

\footnotetext{
4 A belief in a standard of good taste, in contrast to subjective taste and relativism in taste, was an element of the eighteenth century aesthetics. Alison, who contrasts a good taste with a taste of the less educated viewer, is certainly a representative of the eighteenth century philosophy of beauty. However, there are also elements in his thought which suggest that he believes in relativity of taste. An indepth study of this problem was done by Steven A. Jauss in his article "Associationism and Taste Theory in Archibald Alison's Essays."
} 
Considering the viewer, once he or she embarks on the mood inspired by the painting (i.e., by the elements of its coherent composition and the corresponding uniform emotions), he or she utterly abandons himself or herself in a reverie of emotions that pass on, in an associated train, in the imagination. As Alison puts it,

When any object, either of sublimity or beauty [here, the painting representing a certain mood: solemn or cheerful], is presented to the mind, I believe every man is conscious of train of thought being immediately awakened in his imagination, analogous to the character or expression of the original object. (...) our imagination is seized, and our fancy busied in the pursuit of all those trains of thought, which are allied to this character or expression. (Alison 1790: 2-3)

The mood of the picture eventually turns out to be a starting point for a long process of association of feelings that occurs in our imagination; for, when we contemplate a picture, and our heart is set on a certain kind of mood, we suddenly become distracted from the painting itself and lose ourselves "amid the number of images" and passions associated with those that the artist suggested in the painting. This emotional, or, this ecstatic state, lasts for a while until we "waken from this play of fancy, as form the charm of romantic dream" (Alison 1790: 3). Thus the indicator of quality of a landscape painting is its ability to emotionally awaken the viewer's emotions so as to make him or her oblivious of the painting itself, to divert the viewer's attention from its visual beauty and to turn his or her eyes inwards to the imagination, to become involved in dreamful contemplation of his or her internal states. The painting itself, paradoxically, is a work of genius only if it acts as a trigger and is not in the centre of attention. ${ }^{5}$

The external reality is even far less important to the viewer than what the picture represents. For a truly good landscape painting, as we may infer from Alison's discourse, is not supposed to direct our attention to the external world; to recreate, in our minds, all topographical details of a particular terrain. Instead, a landscape painting, ought to

5 Thomas Dick Lauder in his "Essay on the Origin of Taste" (written as an introduction to Uvedale Price's essays On the Picturesque) criticizes Alison for the fact that his theory of aesthetics leads to an illogical statement that the object of art becomes, eventually, absolutely unimportant and overlooked, once a viewer is involved in his imaginative reverie. "In the long train of meditations to which Mr. Alison refers, in the delightful reveries in which he would make the sense of beauty consist, it is obvious that we must soon lose sight of the external object which gave the first impulse to our thoughts, and, though we may afterwards reflect upon it with increased interest and gratitude as the parent of so many charming images, it is impossible, we conceive, that the perception of its beauty, can ever depend upon a long series of various and shifting emotions.” Feeling as I do, the full force of this observation, I am disposed to think that Mr. Alison's error may be accounted for by the fact, that his own highly poetical and imaginative mind must have been so prone to yield to those delightful reveries of which he makes so much account, as to have led him to overlook the full influence of the primary emotions of beauty by which they were generated" (Dick Lauder 1842: 6). 
be a gate to our internal world of sensibility. It is supposed to open up our mind's eye to see the landscape of our soul, rather than to make our organic eye more acute to the particulars of the external world. As Alison puts it, the landscape painter must employ in his work the language which is not intended to speak "to the eye, but to affect the imagination and the heart" (Alison 1790: 89).

The standards for landscape painting set forth by Alison in his Essays on the Nature and Principles of Taste were not wholly new. Several years before his theoretical work, an increasing number of painters were practising the ideas he promoted. In the latter part of the eighteenth century, romantic (or ideal, or poetic, or imaginative) landscape painting developed, of which the most important representatives were Alexander Cozens, his son and student, John Robert Cozens, Thomas Gainsborough, William Gilpin, Richard Wilson and many more (Hardie 1967: 76-77). Cozens Sr. developed a method of so called blotting, i.e., making random blots on a sheet of paper which were to unlock the artist's imagination by suggesting shapes. By means of this exercise of fancy the artist was to be less dependent for inspiration on external nature. ${ }^{6}$ Gainsborough did not look to actual, external nature for most of his ideas. Discussing Gainsborough's method of painting, Joshua Reynolds in his Discourses explains that the artist "framed a kind of model of landscapes on his table, composed of broken stones, dried herbs, and pieces of looking-glass, which he magnified and improved into rocks, trees, and water" (Reynolds 1891: XIV). Furthermore, he had a habit of painting by night, by candlelight (Reynolds 1891: XIV). All this was done to compose a scene coherent in expression; the light of a candle was to add a particular emotional note and saturate the whole view with colour communicating dreamy atmosphere. Gilpin was also reluctant to faithfully recreate an external scene in his pictures. Rather, he would select from the real landscape only those elements which fitted the composition and gave uniform character to his painting (Gilpin 1789: 31-32; Gilpin 1792: 128-129; Gilpin 1808: 166-167).

Gilpin, Gaisnborough, and both Cozenses, and many other British landscapists not only relied more on imagination than on the external nature for composition and colouring, but also believed that what was most important in their paintings was a clearly defined emotional climate, and not the accurate topography of the terrain. As Gilpin says:

In passing through a country you may not have opportunities of giving the exact portrait of any one particular scene, but this is not necessary; perhaps the most useful illustrations of

6 An analysis of this technique is beyond the scope of this article, whose main interest is the theory of A. Alison. The blotting technique and the role of imagination is described by Cozens in his manual for painters entitled A New Method of Assisting the Invention in Drawing Original Compositions of Landscape. Cozen's imaginative approach to painting and his application of the aforesaid method is also discussed in details in Kim Sloan's study Alexander and John Robert Cozens. A Poetry of Landscape in chapter "Teaching at Eaton College and the Various Species of Landscape, \&c. in Nature” (Sloan 1986: 36-62). 
local scenery are those which give the character of the views by pleasing arrangement of ideas taken from the general scene of the country. (Gilpin qtd in Hardie 1967: 77)

Not the topographic details but the overall character of the scene was important, insofar as it struck an emotional note in the viewer and made him or her embark on a dreamful reverie.

\section{Landscape of the mind in nature poetry: The beautiful and the sublime}

Alison's discussion of the sublime and the beautiful, the basic categories in aesthetics introduced in the eighteenth century by Edmund Burke, is relevant to the interpretation of William Wordsworth's nature poem The Prelude. Hence I first clarify Burke's concepts of the beautiful and the sublime, then consider Alison's views on these subjects and then explore how The Prelude can be seen as a poetic counterpart to the Romanticism of the earlier discussed landscape painters.

I need to explain shortly the features of the beautiful and the sublime after Edmund Burke, because his study on this topic was a pioneer one; later theoreticians, including Alison, followed Burke when it comes to considering the qualities of the beautiful and the sublime.

Sublime forms are those that evoke awe and terror in the viewer and they possess such features as vastness, magnitude, obscurity. Beautiful forms, meanwhile. are those which cause the feeling of love in the viewer (Burke 1757: 109). Their characteristic features are smallness, smoothness of outline and gradual variation in the shape, i.e., the beautiful forms are not composed of angular parts (Burke 1757: 138) such as those that we can see, for instance in steep and craggy mountains. A rising sharply high and rugged peak is classified as the sublime one. As to the colours, "soft and cheerful" ones are linked with the beauty (Burke 1757: 100). Colours of beautiful bodies, explains Burke, "must not be dusky or muddy, but clean and fair" (Burke 1757: 141). Such is, for instance, the colouring of a bright summer day. Meanwhile, "dark and gloomy" hues are typical for the sublime aesthetics. So, for instance, the colouring of the "gloomy sky", and that of night, is "solemn" that is to say, exciting sombre feelings and anxiety in the viewer. Such characteristics, which, for Burke, are inherent in the object, ${ }^{7}$ are automatically associated by the viewer with the aforesaid feelings in his mind (Burke 1757: 100).

\footnotetext{
7 Sublime and beautiful characteristics that arise their respective feelings of fear or pleasure, may, but do not necessarily have to be inherent in the object, according to Wordsworth. Sometimes the source of fear and pleasure is in the mind of the spectator and is projected on external objects making them sublime or beautiful. Sometimes the sublimity and beauty are the values inherent in the objects and they evoke the correspondent feelings of fear and pleasure in the viewer. In that case, however, the viewer has a limited ability to discern either beauty or sublimity: it depends on the state of his mind. If he is
} 
Having considered Burke's evaluation of the beautiful and the sublime, we can now proceed to the discussion on the beautiful and the sublime in Alison's aesthetics of the natural scene and in William Wordsworth's nature poem The Prelude.

\subsection{Alison - Mind is the creator of the beauty and the sublime}

Alison calls beautiful those objects which give us pleasure, while he describes as sublime those elements of landscape which awake in us fear or solemn feelings (Alison 1790: 3). So, for instance, he claims, we can discern beauty in "the gay lustre of a morning in spring, or the mild radiance of a summer evening" or sublimity in "the savage majesty of a wintry storm, or the wild magnificence of a tempestuous ocean" (Alison 1790: 3). We feel pleasure and awe respectively in the presence of such scenes. Still, the division of landscape into either of the categories and their respective emotional values becomes more complicated as we read on in Alison's Essay. This is because, despite his definitions of the beautiful and the sublime, Alison also insists on the importance of individual perception. "The simple perception of the object," explains Alison, "is insufficient to awake these emotions, unless it is accompanied by this operation of the mind [i.e., the work of imagination]" (Alison 1790: 2). It is the viewer's perspective and his or her role in making a scene beautiful or sublime that I shall now discuss here in the context of Alison's Essay on the Nature and Principles of Taste.

The viewer's contribution is dependent on a number of factors: his or her mental habits; his or her state of mind, however temporary; and his or her individual history, memories and associations. Considering associations, the trains of "pleasing or of solemn thought" that we associate with a scene "arise spontaneously within our minds" and charge an external scene with emotions "with which the objects before us seem to afford no adequate cause" (Alison 1790: 3). Alison is saying here that, because our emotions go beyond what is presented to us, we in effect become painters with our imagination, completing a scene through what our emotions suggest. The trains of associated thoughts of either kind (pleasant, solemn) are not the same in all the viewers and depend on their personal history or on the specific country and culture in which they were brought up. So, for instance, "The scenes themselves may be little beautiful" (Alison 1790: 17), but we can see them as such if we project on them our sentimental memories, for instance those from our childhood or from the national history. Our recollections are enriched by the association between the scene before us and our imagination and then, in turn, those recollections suffuse the scene before us. It is the associations with which our memories are enriched that give, "a kind of sanctity

overwhelmed with fear, for instance, he will notice the sublime elements of the landscape, but overlook the beautiful ones. The subjective nature of sublime and beautiful in Wordsworth will be explained in detail in the current part of the article. 
to the place where they dwelt, and converts every thing into beauty which appears to have been connected with them" (Alison 1790: 16). Sublime associations projected on an otherwise neutral scene, can be those of a heroic battle. "No man, acquainted with English history," explains Alison on the nature of sublime projections of the mind, "can behold the field of Agincourt, without some emotion of this kind" (Alison 1790: 17). The aforesaid heroic associations in the mind of the spectator "diffuse themselves [...] over the scene, and give it a sublimity which does not naturally belong to it" (Alison 1790: 17). Another factor that plays an important role in our creative perception of a natural scene is either the habitual or the temporary disposition of one's mind. The state of mind, permanent or temporary may act in a different way than enriched recollections discussed above. While recollections made us adorn a scene with some objectively inexistent beautiful or sublime features, the permanent or temporary mental state we are in may make us overlook the beauty or the sublimity of a natural scene. The scene might possess the features which Alison mentions as beautiful or sublime [e.g., the "gaiety of the morning" or "the savage majesty of a wintry storm" (Alison 1790: 3)], but we may fail to notice them due to the selective perception determined by our personality type or our actual mood (Alison 1790: 64). So, for example, "the gaiety of Nature" is recognized as beautiful and discerned by a cheerful man, but it remains obscure to "to the man of sadness" (Alison 1790: 64). A melancholy man, looking at a particular scene would overlook its beauty and would not be able to enjoy the pleasant feeling that someone of a positive temperament would derive from it. Such selective perception, which may make us open to or blind to the beauty or sublimity of a scene, may be short-term or habitual (Alison 1790: 65). "Every man must have had opportunity to observe," claims Alison, "that the perception of Beauty" as well as the sublime, "depends also on the temporary," as well as on permanent "sensibility of his mind" (Alison 1790: 65).

To sum up, for Alison, the paramount factor that makes us see a scene as either beautiful (causing pleasure) or sublime (awaking awe and solemn feelings) is our mind rather than the external features of a scene. We project our memories, associations, momentary or long-lasting emotions and it seems the most important contribution to the way we see a landscape. The landscape which we see is, to a large extent, a landscape of our mind.

\subsection{The landscape of the mind in William Wordsworth's Prelude}

I now wish to explore the landscape of the mind in the context of William Wordsworth's The Prelude. I will demonstrate that beautiful and sublime character of the landscape and its atmosphere in the aforesaid nature poem is generated by the viewer's feelings. I will make the point that nature, in the poem, arouses antithetical feelings in the speaker: at one time, pleasant, at another, fearful. 
Wordsworth suggests that all nature is charged with feeling. The elements of the natural scene, i.e., plants, fruit or rocks, are, he believes, "linked (...) to some feeling" (Wordsworth 1850: III 124-38). He endows the natural scene with anthropomorphic or, to be precise, anthropo-psychic features when he writes that "nature's daily face" puts on its various expressions, ranging from "terror" to "love" (Wordsworth 1850: III 124-38). This suggests that nature adopts various expressions ("face of nature"), and Wordsworth attributes to nature a body language through which it communicates its mental states or moods. These moods, namely, terror and love (which are deeper versions of the earlier discussed feelings of fear and pleasure), correspond to the two basic aesthetic categories introduced by Edmund Burke and elaborated upon by, among others, Archibald Alison. These categories are, of course, that of the beautiful (love) and the sublime (terror) (see J. B. Owen "The Sublime and the Beautiful in The Prelude").

Regarding the beauty of nature, it is related in Wordsworth to the feeling of love, but also that of cheerfulness. These pleasant feelings associated with the beauty of nature are discussed in Book II of The Prelude, where the speaker recollects his nostalgia for the village landscape and for his infant outdoor games, after he had moved to the city. Describing the rural scene of his native place (its topographic details) he immediately recollects his cheerful childhood sports (Wordsworth II 1850: 51-3). "Attachment" of the beauty of a place in nature to childhood sentiments and childish pleasurable, joyful feelings is an effect of the association process, the one which I have discussed in the context of Alison in his Essays on the Nature and the Principles of Taste. Thus, technically speaking, Wordsworth "associates" (Alison 1790: 3) in his mind the native Windermere landscape with the emotions characteristic of beauty: pleasant feelings of teenage period (Wordsworth 1850: II 55), the childish delight (Wordsworth 1850: II 52) and the boisterousness of his boyhood (Wordsworth 1850: II 47). It is these emotions, harboured in the speaker's mind and projected on the particular place in nature, that make the scene beautiful. The scene itself does not need to be beautiful and there does not need to be any natural feature in the scene which is itself pleasant. It is the role of the perceiver that is paramount in creating the beauty of the landscape.

No lesser importance is attributed in The Prelude to the role of the human mind in making a perceived scene sublime. In Wordsworth, sublimity is linked with fear, and the viewer's fearful emotion can charge the landscape with sublimity. For example, there is the famous passage concerning the act of stealing of the boat (Book One of The Prelude). Wordsworth brings back childhood memories and relates how he stole a boat tied to a tree. He describes his escape in the stolen vessel. The author informs us that he was aware of the unethical character of his deed. He says,

It was an act of stealth

And troubled pleasure. (Wordsworth 1850: I 361-362) 
Conscious of the evil nature of his exploit, he cannot feel pure joy: his pleasure is tainted by an admixture of a sense of guilt ("troubled pleasure"). His sense of guilt is intermingled with fear of punishment. Possessed by this fear he starts imagining that nature around him speaks to him in a scolding voice: "nor without the voice/ Of mountain-echoes did my boat move on." His impression is that the otherwise normal, acoustic echo-effect is a reprimand that he receives from nature, but in fact it is the voice of his own conscience. He projects his guilt on the surrounding mountains. Furthermore, his fear of punishment is manifested in the following vision of the natural scene: as he pushes off the shore and starts rowing he fixes his eyes,

Upon the summit of a craggy ridge,

The horizon's utmost boundary; far above

Was nothing but the stars and the grey sky. (Wordsworth 1850: I 361)

As he rows on, his position changes and he can see "from behind that craggy steep" another "huge peak" start to emerge; the peak is "black and huge" (hence: ominous, dark; darkness (Burke 1757:100), and large size (Burke 1757: 93) being linked with the sublime) and it "upreared" its giant head "as if with voluntary power instinct." It seems to the speaker that the huge, dark summit

Towered up between me and the stars, and still,

For so it seemed, with purpose of its own

And measured motion like a living thing,

Strode after me. (Wordsworth 1850: I 382-385)

The phenomenon that Wordsworth refers to is an optical illusion, i.e., the apparent motion which results from the change of the position of the observer: as the speaker in the poem advances off the shore, having his eyes fixed in one point on the horizon, he knows that he is moving but he fears that he is not fast enough. His fear is that the mountain will overtake him. Thus he attributes his own motion to the mountain. Furthermore he projects his own mood on the external world endowing the mountain with ominous properties: his belief that the mountain is following him, apparently with an intention of punishing him for his deed, is a construct of his troubled mind, overwhelmed with terror. The size and dark hue of the mountain is enhanced by the extreme dread in the viewer; or rather, the viewer focusses his attention on the most sublime elements, darkest colours and enormous shapes, unconsciously ignoring everything that does not harmonize with his mood. The perception of the scene is certainly selective, tendentious, and, to a large extent, dependent on the projection by the viewer of his own mental state. Here, Wordsworth's poem dramatizes the theory that Alison 
proposes: we chose to see and contemplate some qualities in nature, while we remain indifferent to others, "because these alone are the qualities which accord with the [our] Emotions" (Alison 1790: 65).

A further example that emphasises the above discussed point, i.e., that the mood pervading natural scene in Wordsworth's poetry is an emanation of the perceiver's state of emotions, is to be found in Wordsworth's poem "Intimations of Immortality from Recollections of Early Childhood." There is a short passage there which well illustrates how the mind makes a scene sublime. "The clouds that gather round the setting sun," writes Wordsworth, "do take a sober colouring from the eye" (Wordsworth 18021804: 196-197). ${ }^{8}$ The tonality in the landscape (the gathering clouds, which portend the onset of darkness) is the projection of our mood; the creeping darkness, symbolically is linked with the feelings of fear, related to the sublime. This feeling is transferred from the viewer ("the eye") to the surrounding world. It is thus the mind and mind alone that is in focus of Wordsworth's nature poetry. It is the internal landscape rather than the outside one that the speaker in the poem contemplates. The outside world is only an effect of what Wing Sze Leng calls the "spreading" of the mind "onto the world" (Sze Leung 2015: 91). ${ }^{9}$

Wordsworth thus creates the landscape of the mind. He echoes the Alisonian rule that a state of mind, as well as the individual associations and trains of thought, determine the viewer's response to forms in nature and, investing them with his or her mood, the viewer enjoys their sublimity or beauty. The role of the external natural scene is that of a mirror reflection of the viewer's mind. A particular place in nature may contain forms and colours that are evocative of sublime or beautiful feelings, but it is the viewer who chooses to discern only those features of the landscape (either only beautiful ones or only sublime ones) which harmonize with his mood. At other times, the scene itself is neither beautiful nor sublime, but is charged by the viewer with the pleasant or awe-inspiring memories and associations and hence it appears to him as beautiful or sublime.

\section{Conclusions}

By the end of the eighteenth century there developed a trend in landscape painting and in nature poetry whose practitioners turned away from a mere representation of nature in itself. No matter how paradoxical it seems to be that a landscape painter or a nature

\footnotetext{
8 Norman Lacey refers to this fragment when he coins the phrase "landscape of the mind" (Lacey 1948: 98-99) which became an inspiration for the current article.

9 Sze Leung borrows the metaphor of the mind spreading "onto the world" from David Hume (Hume, David. 1739. A Treatise on Human Nature http://www.gutenberg.org/cache/epub/4705/pg4705.txt, 12 December 2019) and uses it also in his analysis of William Wordsworth's poetry (Sze Leung 2015: 91).
} 
poet should divert his or her eyes from nature, it became an artistic practice at the end of the eighteenth and turn of the nineteenth centuries. This practice was supported by aesthetic theory. A representative of the eighteenth century aesthetic thought who defended this approach to nature was Archibald Alison. Alison believed that the natural scene should not be an object of imitation but a trigger for inner musings, a starting point of associative process or a vehicle for projections of poet's, painter's or viewer's emotions. Furthermore, he believed that human perception is subjective, that man creatively manipulates nature and selects from it only those elements which can inform or augment his or her habitual or temporary mental state.

Such theoretical concepts as those of Alison underlay the art and poetry of his era in terms of some key figures. So, for instance, such landscape painters as Alexander Cozens or Thomas Gainsborough, relied on their imagination more than on the external world. Furthermore, Gainsborough and William Gilpin believed that a landscape painting ought not to imitate nature but should have a uniform mood so as to speak to the viewer's innermost feelings, and, by spurring his passions, to make him, as Alison puts it, fly "on the wing" of fancy, quit the visible objects, and let the external nature and the landscape painting itself subsumed by the workings of the viewer's mind and emotions (Alison 1790: 42-43). A similar tendency to focus on the inner landscape rather than on the external nature can be seen in the nature poetry of William Wordsworth. In Wordsworth's Prelude the natural scene is coloured by the speaker's mind: his recollections, associations, and his emotions. His perception of nature as beautiful or sublime is an effect of what the poet's mind puts into it. Nature is a receptacle of the poet's joys and fears. What he sees is the landscape of the mind rather than the objective natural world.

The landscape of the mind seems to have been a part of the eighteenth century milieu: it became a subject of landscape painting and nature poetry, and a topic of discussion in the aesthetic theory.

\section{References}

Alison, A. 1790. The Essays on the Nature and Principles of Taste. Edinburgh: Printed for J. J. G., and G. Robinson, London, and Bell and Bradfute.

Andrews, M. 1990. The Search for the Picturesque. Landscape, Aesthetics and Tourism in Britain, 1760-1800. Aldershot: Scolar Press.

Bathe, J. 1991. Romantic Ecology. Wordsworth and the Environmental Tradition. Oxon, New York: Routledge.

Burke, E. 1757. A Philosophical Inquiry Into the Origin of Our Ideas of the Sublime and Beautiful with an Introductory Discourse Concerning Taste, and Several Other Additions. Guttenberg Project, https://www.gutenberg.org/files/15043/15043-h/15043-h.htm\#A_ PHILOSOPHICAL_INQUIRY. (21 September 2015). 
Clarke, M. 1981. The Tempting Prospect. A Social History of English Watercolours. London: British Museum Publications.

Cozens, A. 1785. A New Method of Assisting the Invention in Drawing Original Compositions of Landscape. London: Printed for the Author by, J. Dixwell in St. Martin's Lane.

Dick Lauder, T. 1842. Essay on the origin of taste. In: U. Price, On the Picturesque, with an Essay on the Origin of Taste, and much Original Matter, by Thomas Dick Lauder, Bart, 1-58. Edinburgh: Caldwell, Lloyd, And Co.

Engell, J. 1999. The Creative Imagination. Enlightenment to Romanticism. San Jose: Harvard University Press.

Gilpin, W. 1789. Observations on the River Wye, and Several Parts of South Wales, Ec: Relative Chiefly to Picturesque Beauty, Made in the Summer of the Year 1770. London: R. Blamire, in the Strand.

Gilpin, W. 1792. Observations on Several Parts of England, Particularly the Mountains and Lakes of Cumberland and Westmoreland Relative to Picturesque Beauty, Made in the Year 1772. London: Printed for L. Balmire, Strand.

Gilpin, W. 1808. Three Essays: on Picturesque Beauty; on Picturesque Travel; and on Sketching Landscape: with a Poem on Landscape Painting. London: T. Cadell and W. Davies, Strand.

Hardie, M. 1967. Water-Colour Painting in Britain. The Eighteenth Century. London: B.T. Batsford Ltd.

Hipple, W. J. 1957. The Beautiful, The Sublime, \& The Picturesque In Eighteenth-Century British Aesthetic Theory. Carbondale: The Southern Illinois University Press.

Hume, D. 1739. A Treatise on Human Nature http://www.gutenberg.org/cache/epub/4705/ pg4705.txt (12 December 2019).

Jauss, S. A. 2006. Associationism and taste theory in Archibald Alison's essays. The Journal of Aesthetics and Art Criticism 64(4): 415-428. https://www.jstor.org/stable/4622187 (10 December 2019).

Kallich, M. 1970. The Association of Ideas and Critical Theory in Eighteenth-Century England. A History of a Psychological Method in English Criticism. The Hague/Paris: Mouton \& Co. N.V., Publishers.

Lacey, N. 1948. Wordsworth's Idea of Nature and Its Ethical Consequences. Cambridge: At the University Press.

Owen, J. W. B. 1973. The sublime and the beautiful in The Prelude. The Wordsworth Circle 4(2): 67-86. https://www.jstor.org/stable/24039116 (March 2020).

Price, U. 1842. On the Picturesque. With An Essay on the Origin of Taste, and Much More Original Matter. Edinburgh: Caldwell, Lloyd and co.

Reynolds, J. 1891. Discourses on Art. Chicago: A. C. McClurg and Company. http://archive . org/stream/sirjoshuareynoldø@reynuoft\#page/n9/mode/2up (20 July 2013).

Sloan, K. 1986. Alexander and John Robert Cozens. The Poetry of Landscape. New Heaven/ London: Yale University Press. 
Sze Leung, W. 2015. The ethical importance of the beautiful: Wordsworth's revision of Hume's associationist aesthetics in the 1805. Interdisciplinary Literary Studies 17(1): 86$-109$.

Wordsworth, W. 1802-1804. Ode: Intimations of Immortality from Recollections of Early Childhood. In: M. H. Abrams (ed), 1986. The Norton Anthology of English Literature, 209-216. New York/London: W. W. Norton \& Company.

Wordsworth, W. 1850. The Prelude. In: M. H. Abrams (ed), 1986. The Norton Anthology of English Literature, 227-311. New York/London: W. W. Norton \& Company.

\section{$* * *$}

Marta Oracz graduated from the University of Silesia. In 2002 she was granted a PhD degree in Literature. She works at the University of Silesia. Her field of study is British literature and culture. She is interested in eighteenth century literature, philosophy, aesthetic theories and landscape painting. 